\title{
Hands-off? Laissez-faire policies on Covid-19 may exacerbate health inequalities
}

\author{
William Foley and Klarita Gërxhani \\ Department of Social and Political Sciences, European University Institute, \\ Fiesole, Italy
}

\begin{abstract}
Purpose - This paper establishes an association between income and the likelihood of seeking medical treatment for Covid-19 symptoms in some countries. We provide an explanation for this income effect based on the stringency of government response to the pandemic and the unequal distribution of agency among social classes. Design/methodology/approach - The paper makes use of data from the Six-Country Survey on Covid-19 to establish the existence of an income effect on health utilisation, and from the Oxford Covid-19 Government response tracker to show that this income effect is associated with the stringency of governmental response to the pandemic. Data from the 2011/12 "Health and Healthcare" round of the International Social Survey Programme is used to show that this income effect cannot be explained by pre-existing patterns. An explanation for the link between government stringency and the income effect is advanced on a theoretical basis.

Findings - The authors find in Britain, the US, and - with greater uncertainty - in Japan that individuals who experience potential Covid-19 symptoms are less likely to seek medical treatment if they have a lower income. The authors also show that governments in these countries adopted a less stringent response to the pandemic than the countries in our sample which do not exhibit an income effect - China, Italy and South Korea. The authors argue that laissez-faire policies place the burden of action upon the individual, activating underlying differences in agency between the social classes, and making (high) low-income individuals (more) less likely to seek medical attention.

Research limitations/implications - Since there was not a direct measure of agency in the data, it could not be empirically verified that agency mediates the effect of government stringency on health utilisation. Further research could make use of datasets which incorporate such a measure, if they become available. It could also extend the geographical scope of the findings, to see if the income effect manifests in other countries which adopted a laissez-faire response to the pandemic.

Practical implications - Governments should intervene more stringently during pandemics to minimise inequality in health outcomes.

Originality/value - This paper establishes an association between the stringency of government response to the Covid-19 pandemic and income inequality in health utilisation. This contributes to scholarly and policy debates around health inequality in the area of social epidemiology, and the sociology of inequality more generally. It is also of relevance to the general public, in the context of a deadly pandemic.
\end{abstract}

Keywords Health inequality, Covid-19, Agency, Social class, Laissez-faire, Public policy

Paper type Research paper

\section{Introduction}

It has long been recognised that the relatively poor have higher mortality and morbidity rates than their wealthier counterparts (Wilkinson and Pickett, 2010; Layte et al., 2019). On this basis we would expect the negative health consequences of the Covid-19 pandemic to manifest themselves disproportionately among the lower social classes. In this research note, we present evidence of inequality in health utilisation between higher and lower income groups in several countries. We also propose a tentative theoretical explanation for this

Funding: This research did not receive any specific grant from funding agencies in the public, commercial, or not-for-profit sectors.

Competing interests: The authors have no competing interests to declare.

Received 9 June 2020 Revised 13 June 2020 Accepted 13 June 2020
Laissez-faire policies on Covid-19

(1)


finding based on an interaction between the unequal distribution of personal agency among social classes and the stringency of government intervention during the pandemic.

\section{Method}

We use a recently released dataset to examine the likelihood of contacting the doctor when experiencing potential Covid-19 symptoms. The data come from the Six-Country Survey on Covid-19 (Belot et al., 2020) that collected random samples of circa 1,000 respondents from six countries - Britain, the USA, Japan, South Korea, and China - during the third week of April 2020. To test the relationship between income groups and health utilisation, we ran a separate regression for each country.

The analytic sample was first restricted to those respondents who reported experiencing a Covid-19 related symptom such as a fever, cough or runny nose. These symptoms may, of course, be a manifestation of a common and trivial ailment. It is up to the individual to decide whether to seek medical advice - only $25 \%$ did across all six countries in the sample. A binary-dependent variable was constructed which took a value of 1 if the respondent consulted a doctor or other health authorities, and 0 if they did not. The main independent variable of interest is the quintile of the national income distribution to which the respondent belongs. In the survey, respondents were asked to place themselves in one of five income ranges (e.g. " $\$ 23,001-\$ 42,000 "$ ) corresponding to the quintiles of the national income distribution, as estimated in the Luxembourg Income Study (Belot et al., 2020).

Though the dependent variable is binary, models were fitted using ordinary least squares. This was done because the parameters in logistic models change with the introduction of additional variables, even if they are orthogonal, making interpretation and comparison of coefficients difficult (Mood, 2010). Robustness checks using logistic regression showed no substantive difference from the linear probability model. The output from these robustness checks is presented in Table A2 of the Appendix, with a corresponding coefficient plot (Figure A1).

A battery of control variables were also included in the regressions. First we controlled for the individual's ability to actually get to the clinic by including measures of how frequently they exercised and their cigarette consumption before the pandemic began indicators of physical conditions which can impair movement. Since the pandemic has also made movement by public transport unlawful or unviable, we control for pre-Covid 19 usage of public transport and cars. Secondly, an individual's decision to seek consultation could depend on the information they possess about the nature of the virus. If, when compared to their fellow citizens, they underestimate the virus' prevalence or its negative health consequences then they may be less likely to go to the doctor than those who see it as a greater threat. We thus include variables measuring the respondent's estimation of the rate of asymptomatic infection and the death rate given infection of the virus. Estimation of the effectiveness of public health policies may also influence an individual's threat perception, so we included the respondent's average belief in the effectiveness of seven different items of public health policy: shutting down schools, shutting down public transport, shutting down non-essential business, limiting mobility, forbidding mass gatherings, fining non-compliers, and mask-wearing [1]. Finally, propensity to seek medical advice may be influenced by the presence of family or other household members. For example, the presence of young children, elderly, or infirm individuals may impose timeintensive care responsibilities that become even more onerous during lockdown. Conversely, the presence of able-bodied adults could facilitate medical consultation, through sharing of responsibilities, provision of transport, or other forms of assistance. Individuals may also be motivated to seek medical attention in order to protect family members. Variables (binary) were thus included that measure whether the respondent was sharing their household with children (0-18 years), adults (19-65 years), and over-65s. 
Finally, variables were included measuring the respondent's subjective estimation of whether or not they had been infected, as well as their age, gender and employment status. Including these variables allows us to assume that the difference in income gradient across countries is not due to differences in the observed characteristics of those experiencing symptoms between each country-income quintile. We cannot, of course, rule out selection on unobserved characteristics.

\section{Results and discussion}

The results of the regressions are presented in Table 1 . As they are derived from linear probability models, the coefficients should be interpreted as the effect - in percentage points - of a one unit change in the independent variable on the probability of seeking

\begin{tabular}{|c|c|c|c|c|c|c|}
\hline & Britain & USA & Italy & Korea & China & Japan \\
\hline \multirow[t]{2}{*}{ Income quintile } & $0.047^{* *}$ & $0.053^{* *}$ & -0.026 & 0.001 & -0.023 & $0.034^{*}$ \\
\hline & $(0.014)$ & $(0.018)$ & $(0.018)$ & $(0.013)$ & $(0.020)$ & $(0.017)$ \\
\hline \multirow[t]{2}{*}{ Frequently exercised } & 0.009 & 0.012 & -0.007 & -0.002 & 0.036 & -0.001 \\
\hline & $(0.015)$ & $(0.016)$ & $(0.016)$ & $(0.012)$ & $(0.024)$ & $(0.014)$ \\
\hline \multirow[t]{2}{*}{ Smoked } & 0.023 & 0.010 & 0.014 & -0.001 & 0.014 & 0.005 \\
\hline & $(0.012)$ & $(0.014)$ & $(0.012)$ & $(0.009)$ & $(0.022)$ & $(0.013)$ \\
\hline \multirow[t]{2}{*}{ Used public transport } & 0.002 & $0.049 * *$ & $0.040 * *$ & -0.005 & -0.027 & -0.005 \\
\hline & $(0.014)$ & $(0.016)$ & $(0.015)$ & $(0.012)$ & $(0.022)$ & $(0.014)$ \\
\hline \multirow[t]{2}{*}{ Used car } & -0.016 & $-0.042^{*}$ & -0.009 & 0.010 & 0.030 & 0.021 \\
\hline & $(0.015)$ & $(0.020)$ & $(0.021)$ & $(0.013)$ & $(0.024)$ & $(0.016)$ \\
\hline \multirow{2}{*}{$\begin{array}{l}\text { Belief: proportion of } \\
\text { infected asymptomatic }\end{array}$} & -0.001 & $-0.002^{*}$ & -0.001 & -0.000 & 0.000 & -0.000 \\
\hline & $(0.001)$ & $(0.001)$ & $(0.001)$ & $(0.001)$ & $(0.001)$ & $(0.001)$ \\
\hline \multirow{2}{*}{$\begin{array}{l}\text { Belief: proportion of } \\
\text { infected die }\end{array}$} & $0.002^{*}$ & $0.002^{*}$ & 0.001 & $-0.002 *$ & 0.001 & 0.000 \\
\hline & $(0.001)$ & $(0.001)$ & $(0.001)$ & $(0.001)$ & $(0.001)$ & $(0.001)$ \\
\hline \multirow{2}{*}{$\begin{array}{l}\text { Belief: effectiveness of } \\
\text { public health policies }\end{array}$} & -0.001 & -0.005 & 0.004 & $-0.044^{*}$ & $-0.108^{* * * *}$ & -0.025 \\
\hline & $(0.022)$ & $(0.021)$ & $(0.023)$ & $(0.021)$ & $(0.030)$ & $(0.021)$ \\
\hline \multirow[t]{2}{*}{ Living with children } & -0.005 & $0.090 *$ & $0.116^{* * *}$ & 0.029 & -0.083 & 0.002 \\
\hline & $(0.040)$ & $(0.045)$ & $(0.044)$ & $(0.038)$ & $(0.053)$ & $(0.047)$ \\
\hline \multirow[t]{2}{*}{ Living with adults } & $-0.114^{* *}$ & 0.036 & -0.022 & 0.028 & 0.043 & -0.062 \\
\hline & $(0.040)$ & $(0.045)$ & $(0.051)$ & $(0.037)$ & $(0.076)$ & $(0.043)$ \\
\hline \multirow[t]{2}{*}{ Living with seniors } & -0.009 & 0.027 & -0.004 & 0.045 & 0.120 & 0.069 \\
\hline & $(0.058)$ & $(0.053)$ & $(0.051)$ & $(0.040)$ & $(0.082)$ & $(0.047)$ \\
\hline \multirow{2}{*}{$\begin{array}{l}\text { Belief: probability that } \\
\text { self is infected }\end{array}$} & $0.002^{* *}$ & 0.002 & $0.002^{*}$ & $0.004^{* * * *}$ & 0.003 & $0.004^{* * * *}$ \\
\hline & $(0.001)$ & $(0.001)$ & $(0.001)$ & $(0.001)$ & $(0.002)$ & $(0.001)$ \\
\hline \multicolumn{7}{|c|}{ Employment status (employed $=$ reference category) } \\
\hline \multirow[t]{2}{*}{ Employed part-time } & 0.001 & -0.050 & -0.047 & -0.027 & -0.017 & 0.050 \\
\hline & $(0.052)$ & $(0.070)$ & $(0.065)$ & $(0.052)$ & $(0.113)$ & $(0.052)$ \\
\hline \multirow[t]{2}{*}{ Self-employed } & -0.053 & 0.092 & -0.062 & 0.085 & -0.075 & -0.004 \\
\hline & $(0.064)$ & $(0.079)$ & $(0.056)$ & $(0.048)$ & $(0.076)$ & $(0.076)$ \\
\hline \multirow[t]{2}{*}{ Not in employment } & -0.012 & -0.092 & -0.091 & 0.006 & $-0.310^{* *}$ & 0.048 \\
\hline & $(0.051)$ & $(0.054)$ & $(0.057)$ & $(0.039)$ & $(0.116)$ & $(0.061)$ \\
\hline \multirow[t]{2}{*}{ Age group } & $-0.053^{* * *}$ & -0.013 & -0.021 & 0.009 & 0.012 & -0.022 \\
\hline & $(0.014)$ & $(0.014)$ & $(0.015)$ & $(0.010)$ & $(0.021)$ & $(0.014)$ \\
\hline \multirow[t]{2}{*}{ Male } & $0.111^{* * *}$ & $0.177 * * *$ & $0.090 *$ & 0.004 & -0.012 & -0.055 \\
\hline & $(0.036)$ & $(0.042)$ & $(0.041)$ & $(0.032)$ & $(0.054)$ & $(0.040)$ \\
\hline \multirow[t]{2}{*}{ Constant } & 0.14 & 0.062 & 0.245 & 0.171 & $0.785 * * *$ & 0.108 \\
\hline & $(0.131)$ & $(0.142)$ & $(0.153)$ & $(0.111)$ & $(0.200)$ & $(0.122)$ \\
\hline Observations & 429 & 426 & 459 & 446 & 406 & 323 \\
\hline
\end{tabular}$$
\text { points - of a one unit change in the independent variable on the probability of seeking }
$$

\section{Laissez-faire policies on Covid-19}

Note(s): Standard errors in parentheses. $* p<0.05, * * p<0.01, * * * p<0.001$

\section{Table 1.} each country. Dependent variable: probability of seeking medical attention if experiencing Covid-19 symptoms 
medical assistance given the presence of potential Covid-19 symptoms. The point estimates and $95 \%$ confidence intervals for the explanatory variable of interest - income quintile of respondent - for each country are also presented in a coefficient plot (Figure 1). As can be seen, the effect of income quintile is statistically significant for both the British and the US samples, with a one unit increase in income quintile associated with about a five percentage point increase in the probability of seeking medical assistance. This variable is also statistically significant for the Japanese sample, with a slightly smaller point estimate [2]. However, as can be seen from the coefficient plot, the 95\% confidence interval just barely avoids cross the $y$-axis and so it may be that this result is not particularly robust to different model specifications [3]. Thus, we do not "highlight" this result, though we bear it in mind in the following discussion.

While the income gradient in the US could be explained by the cost of healthcare access which presents a financial barrier to poorer people, this explanation cannot hold for Britain where healthcare is costless at the point of access. Moreover, in Italy, where the healthcare system is also costless at the point of access (France et al., 2005), there is no such income gradient - suggesting that there should be an alternative explanation beyond the direct or indirect costs of healthcare access.

One possible explanation is that the income gradient in seeking treatment is due to a prepandemic association. In order to investigate this, we ran a series of bivariate regressions to test the relationship between household income and a variety of dependent variables related to health utilisation. The data was taken from the "Health and Healthcare" round of the International Social Survey Programme. This round of the survey contained data collected in 2011 and 2012 from all six countries of interest to us. For each outcome variable, a regression model was fitted to data pooled from all countries, with an interaction term included between household income and country. This interaction term allows us to test the difference in slopes of the household income variable between countries. The five dependent variables of interest were: (1) trust in doctors, (2) confidence in the national healthcare system, (3) belief that one would get the best treatment if seriously ill, (4) being

Figure 1.

Plot of the coefficients on income quintile for each country. Dependent variable: probability of contacting doctor if experiencing potential Covid-19 symptoms

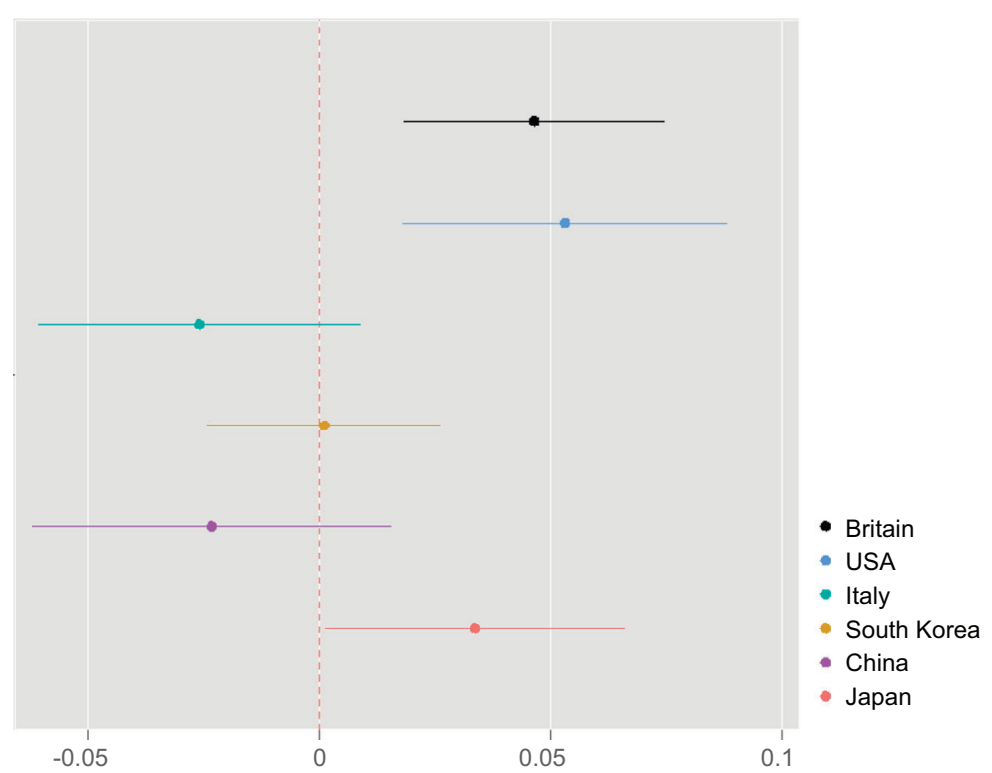

- Britain

South Korea

- China 0.1 
unable to afford medical treatment in the last 12 months, (5) being unable to receive medical treatment due to work or other commitments in the last 12 months. The interaction terms for each regression are presented in Table 2 below. China is the reference category, so the point estimates tell us the difference between the slope of household income in a given country and the slope for China. Household income was standardised within each country, and weights were applied to account for different probability of being surveyed within countries. Ordered logistic regressions were fitted for models (1), (2), and (3); logistic regressions for models (4) and (5).

If our finding of an income gradient in seeking treatment for coronavirus symptoms were to be explained by pre-pandemic characteristics, we would expect to see that Italy and South Korea are not meaningfully different from China, whereas Britain, the USA and Japan should all be significantly different. Or, if we do find meaningful differences for Italy and South Korea, they should be opposite in sign to the coefficients for Britain, the USA, and Japan. However, as can be seen from the table, neither pattern emerges. Not even one of the models shows a clustering of income effects between our two groups of countries. It seems that the income gradient in seeking treatment for Coronavirus cannot be explained by pre-pandemic differences between countries in trust in doctors and the health system, or ability to access healthcare.

What accounts for the pattern observed in the Six Country Survey on Covid-19? We suggest that the income gradient in healthcare access could be driven by less stringent responses of national governments at the outbreak of the pandemic. By choosing not to intervene stringently in day-to-day life, governments leave people to their own devices, thereby rendering persons with low agency - such as poorer people - less likely to take action.

Agency refers to an individual's perception of their control over their actions and their ability to influence the external world through those actions (Tapal et al., 2017; Snibbe and Markus, 2005). Poorer individuals tend to have a lesser sense of agency as they do not always have the economic resources to exert control over their lives and external circumstances

\begin{tabular}{|c|c|c|c|c|c|}
\hline $\begin{array}{l}\text { Dependent } \\
\text { variable }\end{array}$ & $\begin{array}{l}1 \\
\text { Trust in } \\
\text { doctors }\end{array}$ & $\begin{array}{c}2 \\
\text { Confidence in } \\
\text { health system }\end{array}$ & $\begin{array}{l}3 \\
\text { Likely to get best } \\
\text { treatment }\end{array}$ & $\begin{array}{c}4 \\
\text { Couldn't afford } \\
\text { treatment }\end{array}$ & $\begin{array}{l}5 \\
\text { No time for } \\
\text { treatment }\end{array}$ \\
\hline China & [reference] & [reference] & [reference] & [reference] & [reference] \\
\hline Italy & $\begin{array}{c}-0.28^{* * *} \\
(0.07)\end{array}$ & $\begin{array}{c}-0.34^{* * * *} \\
(0.07)\end{array}$ & $\begin{array}{c}0.04 \\
(0.01)\end{array}$ & $\begin{array}{l}6.14^{* * * *} \\
(0.87)\end{array}$ & $\begin{array}{c}0.45 \\
(0.38)\end{array}$ \\
\hline Korea & $\begin{array}{l}0.250 * * * \\
(0.07)\end{array}$ & $\begin{array}{c}0.06 \\
(0.05)\end{array}$ & $\begin{array}{c}-0.11 \\
(0.09)\end{array}$ & $\begin{array}{l}5.54^{* * * *} \\
(0.88)\end{array}$ & $\begin{array}{c}0.74 * \\
(0.33)\end{array}$ \\
\hline Japan & $\begin{array}{c}0.01 \\
(0.07)\end{array}$ & $\begin{array}{c}0.00 \\
(0.05)\end{array}$ & $\begin{array}{c}-0.09 \\
(0.08)\end{array}$ & $\begin{array}{l}5.95^{\text {**** }} \\
(0.90)\end{array}$ & $\begin{array}{c}0.60 \\
(0.34)\end{array}$ \\
\hline Britain & $\begin{array}{r}-0.08 \\
(0.08)\end{array}$ & $\begin{array}{r}-0.02 \\
(0.07)\end{array}$ & $\begin{array}{c}0.16 \\
(0.09)\end{array}$ & $\begin{array}{l}6.96^{\text {**** }} \\
(0.86)\end{array}$ & $\begin{array}{c}0.67 \\
(0.36)\end{array}$ \\
\hline USA & $\begin{array}{l}-0.34^{* * * *} \\
(0.07)\end{array}$ & $\begin{array}{c}-0.15^{* *} \\
(0.06)\end{array}$ & $\begin{array}{c}-0.29 * * * \\
(0.09)\end{array}$ & $\begin{array}{l}6.53^{* * *} \\
(0.84)\end{array}$ & $\begin{array}{c}0.50 \\
(0.35)\end{array}$ \\
\hline Observations & 10,605 & 10,515 & 10,393 & 8,081 & 8,124 \\
\hline
\end{tabular}

Note(s): Standard errors in parentheses. $* p<0.05, * * p<0.01, * * * p<0.001$

Dependent variables

(1) Doctors can be trusted $[1$ = strongly agree . . .5 = strongly disagree]; (2) How much confidence in healthcare system? $[1=$ complete confidence . . .5 = no confidence at all]; (3) How certain to get best treatment if seriously ill? $[1=$ certain I would get . . .5 = certain I would not get $]$; (4) could not afford treatment last 12 months $[0=$ no, $1=$ yes]; (5) did not have time for treatment last 12 months $[0=$ no, $1=$ yes $]$

Functional form: (1) (2) (3) — Ordinal logistic. (4) (5) — Logistic

Laissez-faire policies on Covid-19

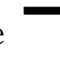


(Kraus et al., 2012; Lachman and Weaver, 1998). Moreover, the type of work done by those in low-income occupations also seems to attenuate their sense of agency. Such individuals usually occupy positions of less authority and autonomy (Kohn et al., 1990; Snibbe and Markus, 2005), something which diminishes their sense of control over themselves and their circumstances (Enagly and Steffe, 1984; Conway et al., 1996).

Persons lacking in agency are less likely to seek medical attention and follow medical guidelines (Rutger, 2007). This may be partly due to fact that low agency individuals tend to have a fatalistic attitude towards life (Tapal et al., 2017). When presenting potential symptoms of Covid-19, poorer people may thus feel that the implications for health are "out of their hands" - dependent on chance rather than on their own actions. They will not seek medical assistance, hoping that the problem resolves itself. The role of agency may be particularly salient in the context of a cross-class interaction between a lower-income individual and a medical professional, where the former is likely to feel an even greater diminution of their agency (Ridgeway and Fisk, 2012).

East Asian countries place less emphasis on agency as a normative model of behaviour at least in the sense of individual action undertaken without orientation towards others (Huajian et al., 2012; Markus and Kitayama, 1991). They are thus less likely to associate agentic behaviour with economic success, and so individuals from different income groups may be less likely to internalise stereotypes about the level of agency typical of their socioeconomic position. The more muted differential in agency between income groups may account for the absence of an income gradient in China and South Korea, and the smaller coefficient in Japan - though it does not explain the absence of an effect in Italy.

Our argument is that individual agency is (de)activated by the public policy response to the pandemic. In countries with a more laissez faire mentality, governments may respond later to prevention and treatment, which means more responsibility is placed in the hands of the individual. Individuals with low agency will be less likely to take action - because of their more fatalistic attitude they feel that action would be futile or of limited utility. And where distributions of agency vary across income groups, income groups will also vary in taking a pro-active response to the challenges posed by the pandemic - such as deciding whether to seek medical attention when experiencing potential Covid-19 symptoms.

The countries in our dataset which show a zero income gradient in health utilisation are those where there was also massive, systematic and pervasive government intervention to arrest the development of the pandemic. China and Italy both imposed stringent lockdowns among other measures (Cyranowski, 2020; Tondo, 2020). South Korea implemented rapid and widespread testing, mandatory quarantine of severe cases, and invasive and comprehensive tracing mechanisms which included the use of credit card statements and mobile phone location data (Zastrow, 2020; Thompson, 2020).

On the other hand, the response of the British and US governments was more laissez-faire. In the US case, a national lockdown was imposed at a relatively late stage and undermined by comments made by the country's president (Gearan and Wagner, 2020). In the British case, stringent health measures were implemented only at a relatively late stage after reversing earlier plans for lighter restrictions (Yong, 2020). As with the US president, the UK prime minister's personal advice and behaviour also undermined social distancing recommendations - on the same day that his scientific advisory group warned against close physical contact, Boris Johnson "boasted about [shaking hands] "with everybody" at a hospital where there were confirmed coronavirus patients” (Mason, 2020).

In Japan - where we find (more uncertain) evidence of an income gradient - the government has also been less interventionist in its policy than its East Asian neighbours. It has not imposed a legally-enforced lockdown or engaging in extensive testing (Normile, 2020). Given the combination of collectivist culture and light-touch pandemic policy, we would expect Japan to be an intermediate case between countries with individualist cultures which 
followed a laissez-faire strategy - such as the US and Britain - and collectivist cultures where the government was strongly interventionist-such as China and South Korea. To the extent that the greater uncertainty around the estimate of the Japanese income gradient simply reflects a statistical artefact - such as a relatively low sample size of those reporting potential symptoms - our tentative explanation can be expressed more parsimoniously: countries whose governments adopted a more laissez-faire approach to the pandemic exhibit a greater income gradient in health service utilisation.

Our argument is given further credence by data taken from the Oxford COVID-19 Government Response Tracker (Hale et al., 2020). This dataset tracks the implementation of public policies in response to Covid-19, and includes a "stringency index" - an index measuring the overall intensity of government intervention during the pandemic that summarises the score on nine different policy items. We calculated the mean value of the index for our six countries for the period from the beginning of the (Oxford) data series to the last day of data collection for the Six Countries survey (15-23 April). We then plotted these mean stringency values against the income gradient coefficients for each country from the OLS estimates presented in Table 1. This plot is presented in Figure 2. As can be seen from the graph, there is a clear negative association between the stringency of government intervention in response to the pandemic and the divergent probabilities of seeking medical attention across income groups, with the plotted points fitting quite tightly to the straight line. The $p$-values for the coefficients show distinct clustering patterns - with the countries exhibiting a statistically significant income gradient in healthcare utilisation also scoring lower in the stringency index ( $p=0.00$ for Britain and the US and $p=0.04$ for Japan) [4]. Since stringency can be regarded as the opposite of laissez-faire, we view this association as substantial evidence in favour of our argument.

Our study is, of course, correlational. One could argue that the apparent association between stringency of intervention and income gradient is confounded by an anterior factor: cultural individualism, which both augments the positive relationship between income and

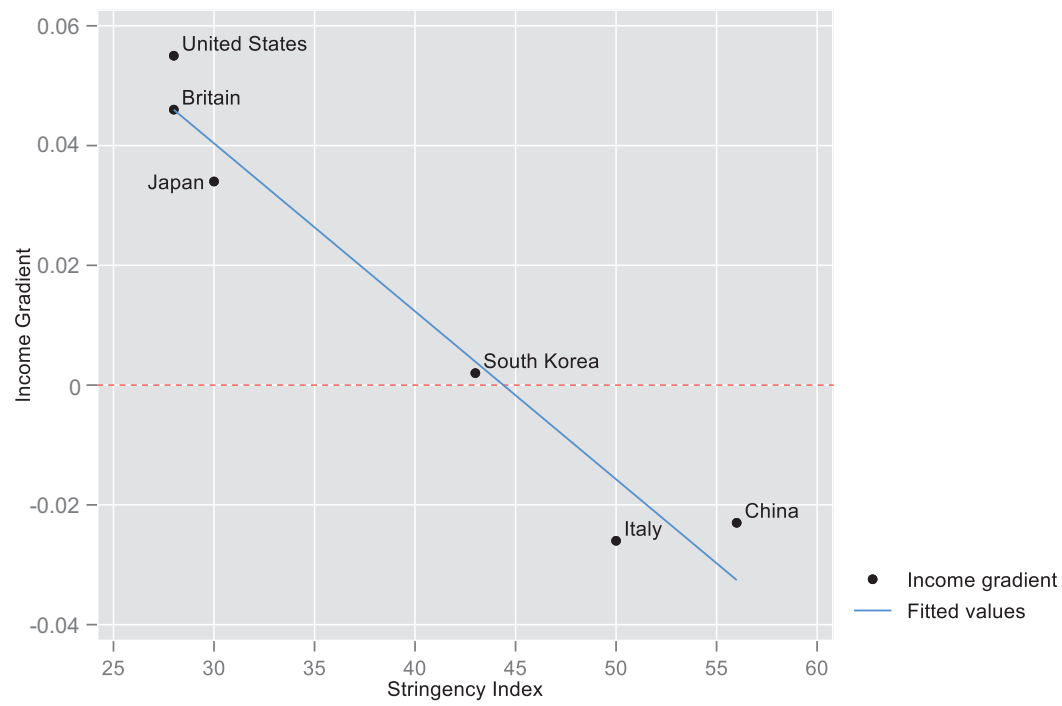

Note(s): The $p$-values for the coefficients are: United States $p=0.00$; Britain $p=0.00$; Japan $p=0.04$; South Korea $p=0.90$; Italy $p=0.14$; and China $p=0.25$
Laissez-faire policies on Covid-19

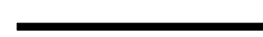


agency and predisposes governments towards a more laissez-faire approach to Covid-19 policy. The relationship between laissez-faire policy and activation of individual agency may thus be spurious or upwardly biased. Although we cannot entirely rule this out, we do wish to comment that this alternative explanation is prima facie inconsistent with results for the Japanese and Italian cases. While Japan is a less culturally individualistic country than Italy (Hofstede et al., 2010), it does have a positive income gradient on the probability of healthcare utilisation where Italy does not. Therefore, even if pre-existing cultural individualism has an effect, it seems to be dominated by a countervailing force. We maintain that this force is the stringency of government intervention.

Finally, the interpretations presented in this note are, of course, speculative. Further research should investigate the interaction between public policy and individual agency and how this interaction affects health service utilisation among social classes during the pandemic. What seems to be undeniable however, is the clear inequality in contacting doctors or health authorities between poorer and richer citizens of the US and Britain. This is particularly concerning given that these countries appear to have experienced death rates of Covid-19 that are amongst the highest in the world (Financial Times, 2020). A potential implication of our findings is that for inequality to decrease and more lives - regardless of income and class - to be saved, moving away from the laissez-faire approach is necessary.

\section{Notes}

1. Scale reliability coefficient $=0.89$ (Cronbach's alpha).

2. Table A1 in the Appendix shows that the association for these three countries also exists in the "raw" data - i.e. at a bivariate level.

3. It should also be said that the greater uncertainty surrounding the point estimate may be largely due to the lower sample size of those reporting potential symptoms in Japan when compared to the other countries.

4. Given the closeness of the standard errors to each other for the income gradients in Table 1, it seems that the variation in statistical significance is being driven primarily by distance of the point estimates from a zero effect of income rather than differing levels of uncertainty in the sample.

\section{References}

Belot, M., Choi, S., Jamison, J.C., Papageorge, N.W., Tripodi, E. and van den Broek-Altenburg, E. (2020), Six-Country Survey on Covid-19, available at: https://osf.io/aubkc/Last (accessed 19 April 2020).

Conway, M., Pizzamiglio, M.T. and Mount, L. (1996), "Status, communality, and agency: implications for stereotypes of gender and other groups", Journal of Personality and Social Psychology, Vol. 71 No. 1, pp. 25-38, doi: 10.1037/0022-351.

Cyranowski, D. (2020), "What China's coronavirus response can teach the rest of the world", Nature, available at: https://www.nature.com/articles/d41586-020-00741-x (accessed 19 April 2020).

Eagly, A.H. and Steffen, V.J. (1984), "Gender stereotypes stem from the distribution of women and men into social roles", Journal of Personality and Social Psychology, Vol. 46 No. 4, pp. 735-754, doi: 10.1037/0022-3514.46.4.735.

Financial Times (2020), “Coronavirus Tracked: Has the Epidemic Peaked Near You?”, Financial Times, FT Visual \& Data Journalism Team, available at: https:/ig.ft.com/coronavirus-chart/ (accessed 19 April 2020).

France, G., Taroni, F. and Donatini, A. (2005), "The Italian health-care system”, Health Economics, Vol. 14, pp. S187-S202, doi: 10.1002/hec.1035.

Gearan, A. and Wagner, J. (2020), “Trump Expresses Support for Angry Anti-shutdown Protesters as More States Lift Coronavirus Lockdowns", The Washington Post, available at: https://www. 
washingtonpost.com/politics/trump-expresses-support-for-angry-anti-shutdown-protesters-asmore-states-lift-coronavirus-lockdowns/2020/05/01/25570dbe-8b9f-11ea-8ac1-bfb250876b7a_story.html (accessed 19 April 2020).

Hale, T., Webster, S., Petherick, A., Phillips, T. and Kira, B. (2020), Oxford COVID-19 Government Response Tracker, Blavatnik School of Government, available at: https://www.bsg.ox.ac.uk/ research/research-projects/coronavirus-government-response-tracker (accessed 19 April 2020).

Hofstede, G., Hofstede, G.J. and Minkov, M. (2010), Cultures and Organizations: Software of the Mind, 3rd ed., McGraw-Hill, New York.

Huajian, C., Kwan, V. and Sedikides, C. (2012), "A sociocultural approach to narcissism: the case of modern China”, European Journal of Personality, Vol. 26 No. 5, pp. 529-535, doi: 10.1002/per.852.

Kohn, M.L., Naoi, A., Schoenbach, C., Schooler, C. and Slomczynski, K.M. (1990), "Position in the class structure and psychological functioning in the United States, Japan, and Poland", American Journal of Sociology, Vol. 95 No. 4, pp. 964-1008, doi: 10.1086/229382.

Kraus, M.W., Piff, P.K., Mendoza-Denton, R., Rheinschmidt, M.L. and Keltner, D. (2012), "Social class, solipsism, and contextualism: how the rich are different from the poor", Psychological Review, Vol. 119 No. 3, pp. 546-572, doi: 10.1037/a0028756.

Lachman, M.E. and Weaver, S.L. (1998), "The sense of control as a moderator of social class differences in health and well-being", Journal of Personality and Social Psychology, Vol. 74 No. 3, pp. 763-773, doi: 10.1037/0022-3514.74.3.763.

Layte, R., McCrory, C., NíCheallaigh, C., Bourke, N., Kivimaki, M., Ribeiro, A.I., Stringhini, S. and Vineis, P. (2019), "A comparative analysis of the status anxiety hypothesis of socioeconomic inequalities in health based on 18,349 individuals in four countries and five cohort studies", Scientific Reports, Vol. 796 No. 9, pp. 1-6, doi: 10.1038/s41598-018-37440-7.

Markus, H.R. and Kitayama, S. (1991), "Culture and the self: implications for cognition, emotion, and motivation”, Psychological Review, Vol. 98 No. 2, pp. 224-253, doi: 10.1037/0033-295X.98.2.224.

Mason, R. (2020), "Boris Johnson Boasted of Shaking Hands on Day Sage Warned Not to", The Guardian, available at: https:/www.theguardian.com/politics/2020/may/05/boris-johnsonboasted-of-shaking-hands-on-day-sage-warned-not-to (accessed 19 April 2020).

Mood, C. (2010), "Logistic regression: why we cannot do what we think we can do, and what we can do about it", European Sociological Review, Vol. 26 No. 1, pp. 67-82, doi: 10.1093/esr/jcp006.

Normile, D. (2020), Did Japan Miss its Chance to Keep the Coronavirus in Check?", Science, available at: https://www.sciencemag.org/news/2020/04/did-japan-miss-its-chance-keep-coronavirus-check (accessed 19 April 2020).

Ridgeway, C.L. and Fisk, S.R. (2012), "Class rules, status dynamics, and "gateway" interactions", in Markus, H.R. and Fiske, S.T. (Eds), Facing Social Class: How Societal Rank Influences Interaction, Russel Sage, New York, pp. 131-151.

Ruger, J.P. (2007), "Rethinking equal access: agency, quality, and norms”, Global Public Health, Vol. 2 No. 1, pp. 78-96, doi: 10.1080/17441690600911480.

Snibbe, A.C. and Markus, H.R. (2005), "You can't always get what you want: educational attainment, agency, and choice", Journal of Personality and Social Psychology, Vol. 88 No. 4, pp. 703-720, doi: 10.1037/0022-3514.88.4.703.

Tapal, A., Oren, E., Dar, R. and Eitam, B. (2017), "The sense of agency Scale: a measure of consciously perceived control over one's mind, body, and the immediate environment", Frontiers in Psychology, Vol. 8, pp. 1-11, doi: 10.3389/fpsyg.2017.01552.

Thompson, D. (2020), "What's behind South Korea's COVID-19 Exceptionalism?”, The Atlantic, available at: https://www.theatlantic.com/ideas/archive/2020/05/whats-south-koreas-secret/ 611215/ (accessed 19 April 2020).

Tondo, L. (2020), "Italy charges more than 40,000 people with violating lockdown", The Guardian, available at: https:/www.theguardian.com/world/2020/mar/18/italy-charges-more-than-40000people-violating-lockdown-coronavirus (accessed 19 April 2020). Laissez-faire
policies on
Covid-19 
Wilkinson, R. and Pickett, K. (2010), The Spirit Level, 2nd ed., Bloomsbury, London.

Yong, E. (2020), “The U.K.'s Coronavirus 'Herd Immunity' Debacle”, The Atlantic, available at: https:// www.theatlantic.com/health/archive/2020/03/coronavirus-pandemic-herd-immunity-uk-borisjohnson/608065/ (accessed 19 April 2020).

Zastrow, M. (2020), How South Korea prevented a coronavirus disaster — and why the battle isn't over, National Geographic, available at: https:/www.nationalgeographic.com/science/2020/05/ how-south-korea-prevented-coronavirus-disaster-why-battle-is-not-over/ (accessed 19 April 2020).

\section{Appendix}

\section{Table A1.}

Percentage of those experiencing potential Covid-19 symptoms in each country who have contacted the doctor, by income quintile

\begin{tabular}{lcccccr}
\hline & China & Italy & Japan & Korea & Britain & USA \\
\hline First quintile & $48 \%$ & $29 \%$ & $8 \%$ & $10 \%$ & $9 \%$ & $8 \%$ \\
Second quintile & $62 \%$ & $27 \%$ & $13 \%$ & $7 \%$ & $8 \%$ & $21 \%$ \\
Third quintile & $49 \%$ & $23 \%$ & $6 \%$ & $13 \%$ & $22 \%$ & $31 \%$ \\
Fourth quintile & $45 \%$ & $27 \%$ & $22 \%$ & $11 \%$ & $19 \%$ & $38 \%$ \\
Fifth quintile & $43 \%$ & $22 \%$ & $18 \%$ & $13 \%$ & $25 \%$ & $56 \%$ \\
Total & $49 \%$ & $25 \%$ & $13 \%$ & $11 \%$ & $17 \%$ & $31 \%$ \\
$N$ & 406 & 459 & 323 & 446 & 429 & 427
\end{tabular}

Note(s): As in the regression analyses, the differences between quintiles are statistically significant only in Japan, Britain, and the USA Chi squared tests of independence (four degrees of freedom) between contacting the doctor and income quintile for each country ( $p$-value in parentheses): China $=6.4514(0.168)$; Italy $=1.4847$ $(0.829)$; Japan $=9.6923(0.046) ;$ Korea $=2.3523$ (0.671); Britain = $13.1799(0.010) ; \mathrm{USA}=42.8231(0.000)$ 


\begin{tabular}{|c|c|c|c|c|c|c|c|}
\hline & Britain & USA & Italy & Korea & China & Japan & Laissez-faire \\
\hline Income quintile & $\begin{array}{c}0.31 * \\
(0.13)\end{array}$ & $\begin{array}{c}0.32^{*} \\
(0.12)\end{array}$ & $\begin{array}{c}-0.14 \\
(0.10)\end{array}$ & $\begin{array}{c}0.01 \\
(0.15)\end{array}$ & $\begin{array}{r}-0.10 \\
(0.09)\end{array}$ & $\begin{array}{c}0.34^{*} \\
(0.16)\end{array}$ & Covid-19 \\
\hline Frequently exercised & $\begin{array}{c}0.10 \\
(0.13)\end{array}$ & $\begin{array}{c}0.05 \\
(0.12)\end{array}$ & $\begin{array}{c}-0.04 \\
(0.09)\end{array}$ & $\begin{array}{c}-0.04 \\
(0.14)\end{array}$ & $\begin{array}{c}0.17 \\
(0.11)\end{array}$ & $\begin{array}{c}-0.03 \\
(0.14)\end{array}$ & \\
\hline Smoked & $\begin{array}{c}0.16 \\
(0.10)\end{array}$ & $\begin{array}{l}0.05 \\
(0.09)\end{array}$ & $\begin{array}{c}0.09 \\
(0.07)\end{array}$ & $\begin{array}{r}-0.03 \\
(0.10)\end{array}$ & $\begin{array}{c}0.07 \\
(0.10)\end{array}$ & $\begin{array}{c}0.03 \\
(0.13)\end{array}$ & \\
\hline Used public transport & $\begin{array}{l}0.00 \\
(0.11)\end{array}$ & $\begin{array}{l}0.28^{* *} \\
(0.10)\end{array}$ & $\begin{array}{c}0.20^{*} \\
(0.08)\end{array}$ & $\begin{array}{c}-0.07 \\
(0.13)\end{array}$ & $\begin{array}{c}-0.11 \\
(0.10)\end{array}$ & $\begin{array}{c}-0.04 \\
(0.14)\end{array}$ & \\
\hline Used car & $\begin{array}{c}-0.12 \\
(0.12)\end{array}$ & $\begin{array}{c}-0.27 \\
(0.14)\end{array}$ & $\begin{array}{c}-0.05 \\
(0.12)\end{array}$ & $\begin{array}{c}0.13 \\
(0.16)\end{array}$ & $\begin{array}{c}0.13 \\
(0.11)\end{array}$ & $\begin{array}{c}0.24 \\
(0.17)\end{array}$ & \\
\hline $\begin{array}{l}\text { Belief: proportion of infected } \\
\text { asymptomatic }\end{array}$ & $\begin{array}{c}-0.00 \\
(0.01)\end{array}$ & $\begin{array}{c}-0.01 \\
(0.01)\end{array}$ & $\begin{array}{r}-0.00 \\
(0.00)\end{array}$ & $\begin{array}{c}-0.00 \\
(0.01)\end{array}$ & $\begin{array}{l}0.00 \\
(0.01)\end{array}$ & $\begin{array}{c}-0.01 \\
(0.01)\end{array}$ & \\
\hline Belief: proportion of infected die & $\begin{array}{c}0.01 \\
(0.01)\end{array}$ & $\begin{array}{c}0.01 \\
(0.01)\end{array}$ & $\begin{array}{c}0.01 \\
(0.00)\end{array}$ & $\begin{array}{c}-0.03^{*} \\
(0.01)\end{array}$ & $\begin{array}{c}0.00 \\
(0.00)\end{array}$ & $\begin{array}{c}0.00 \\
(0.01)\end{array}$ & \\
\hline $\begin{array}{l}\text { Belief: effectiveness of public } \\
\text { health policies }\end{array}$ & $\begin{array}{c}-0.01 \\
(0.19)\end{array}$ & $\begin{array}{c}-0.05 \\
(0.14)\end{array}$ & $\begin{array}{c}0.04 \\
(0.13)\end{array}$ & $\begin{array}{c}-0.47^{*} \\
(0.22)\end{array}$ & $\begin{array}{c}-0.47 * * * \\
(0.14)\end{array}$ & $\begin{array}{c}-0.18 \\
(0.21)\end{array}$ & \\
\hline Living with children & $\begin{array}{c}0.02 \\
(0.32)\end{array}$ & $\begin{array}{c}0.48 \\
(0.28)\end{array}$ & $\begin{array}{l}0.64 * * \\
(0.25)\end{array}$ & $\begin{array}{c}0.31 \\
(0.40)\end{array}$ & $\begin{array}{c}-0.35 \\
(0.23)\end{array}$ & $\begin{array}{c}-0.09 \\
(0.49)\end{array}$ & \\
\hline Living with adults & $\begin{array}{c}-0.77^{*} \\
(0.34)\end{array}$ & $\begin{array}{c}0.26 \\
(0.31)\end{array}$ & $\begin{array}{c}-0.10 \\
(0.31)\end{array}$ & $\begin{array}{c}0.21 \\
(0.43)\end{array}$ & $\begin{array}{c}0.18 \\
(0.33)\end{array}$ & $\begin{array}{c}-0.53 \\
(0.42)\end{array}$ & \\
\hline Living with seniors & $\begin{array}{c}-0.43 \\
(0.51)\end{array}$ & $\begin{array}{c}0.05 \\
(0.14)\end{array}$ & $\begin{array}{c}0.01 \\
(0.02)\end{array}$ & $\begin{array}{c}0.14 \\
(0.15)\end{array}$ & $\begin{array}{c}0.22 \\
(0.20)\end{array}$ & $\begin{array}{c}0.64^{*} \\
(0.27)\end{array}$ & \\
\hline $\begin{array}{l}\text { Belief: probability that self is } \\
\text { infected } \\
\text { Employment status } \\
\text { (employed = reference category) }\end{array}$ & $\begin{array}{l}0.02 * * \\
(0.01)\end{array}$ & $\begin{array}{c}0.01 \\
(0.01)\end{array}$ & $\begin{array}{l}0.01^{*} \\
(0.00)\end{array}$ & $\begin{array}{l}0.04 * * * * \\
(0.01)\end{array}$ & $\begin{array}{c}0.01 \\
(0.01)\end{array}$ & $\begin{array}{l}0.03^{* * * *} \\
(0.01)\end{array}$ & \\
\hline Employed part-time & $\begin{array}{c}0.06 \\
(0.42)\end{array}$ & $\begin{array}{c}-0.17 \\
(0.43)\end{array}$ & $\begin{array}{c}-0.21 \\
(0.36)\end{array}$ & $\begin{array}{c}-0.25 \\
(0.62)\end{array}$ & $\begin{array}{c}-0.05 \\
(0.49)\end{array}$ & $\begin{array}{c}0.56 \\
(0.51)\end{array}$ & \\
\hline Self-employed & $\begin{array}{c}-0.48 \\
(0.58)\end{array}$ & $\begin{array}{l}0.62 \\
(0.49)\end{array}$ & $\begin{array}{c}-0.31 \\
(0.31)\end{array}$ & $\begin{array}{c}0.71 \\
(0.46)\end{array}$ & $\begin{array}{c}-0.41 \\
(0.34)\end{array}$ & $\begin{array}{c}0.01 \\
(0.74)\end{array}$ & \\
\hline Not in employment & $\begin{array}{c}-0.31 \\
(0.49)\end{array}$ & $\begin{array}{c}-0.57 \\
(0.38)\end{array}$ & $\begin{array}{c}-0.57 \\
(0.34)\end{array}$ & $\begin{array}{c}0.06 \\
(0.45)\end{array}$ & $\begin{array}{c}-1.35^{*} \\
(0.53)\end{array}$ & $\begin{array}{c}0.45 \\
(0.61)\end{array}$ & \\
\hline Age group & $\begin{array}{c}-0.47^{* * * *} \\
(0.12)\end{array}$ & $\begin{array}{c}-0.08 \\
(0.10)\end{array}$ & $\begin{array}{c}-0.14 \\
(0.09)\end{array}$ & $\begin{array}{c}0.12 \\
(0.12)\end{array}$ & $\begin{array}{c}0.06 \\
(0.09)\end{array}$ & $\begin{array}{c}-0.27 \\
(0.15)\end{array}$ & Table A2. \\
\hline Male & $\begin{array}{l}0.82^{* *} \\
(0.31)\end{array}$ & $\begin{array}{l}0.98^{* * * *} \\
(0.27)\end{array}$ & $\begin{array}{c}0.52^{*} \\
(0.24)\end{array}$ & $\begin{array}{c}0.09 \\
(0.36)\end{array}$ & $\begin{array}{c}-0.05 \\
(0.24)\end{array}$ & $\begin{array}{c}-0.54 \\
(0.43)\end{array}$ & $\begin{array}{l}\text { Logistic regressions for } \\
\text { each country. }\end{array}$ \\
\hline Constant & $\begin{array}{c}-1.91 \\
(1.11)\end{array}$ & $\begin{array}{c}-2.19^{*} \\
(0.94)\end{array}$ & $\begin{array}{c}-1.24 \\
(0.87)\end{array}$ & $\begin{array}{c}-1.50 \\
(1.18)\end{array}$ & $\begin{array}{l}1.14 \\
(0.89)\end{array}$ & $\begin{array}{c}-2.51^{*} \\
(1.23)\end{array}$ & $\begin{array}{l}\text { Dependent variable: } \\
\text { probability of seeking } \\
\text { medical attention if }\end{array}$ \\
\hline Observations & 428 & 426 & 459 & 446 & 406 & 323 & experiencing Covid-19 \\
\hline \multicolumn{7}{|c|}{ Note(s): Standard errors in parentheses. ${ }^{*} p<0.05, * * p<0.01, * * * p<0.001$} & symptoms \\
\hline
\end{tabular}




\section{IJSSP}

\section{Figure A1.}

Plot of the coefficients on income quintile for each country, from the logistic regressions in Table A2. Dependent variable: probability of contacting doctor if experiencing potential Covid-19 symptoms

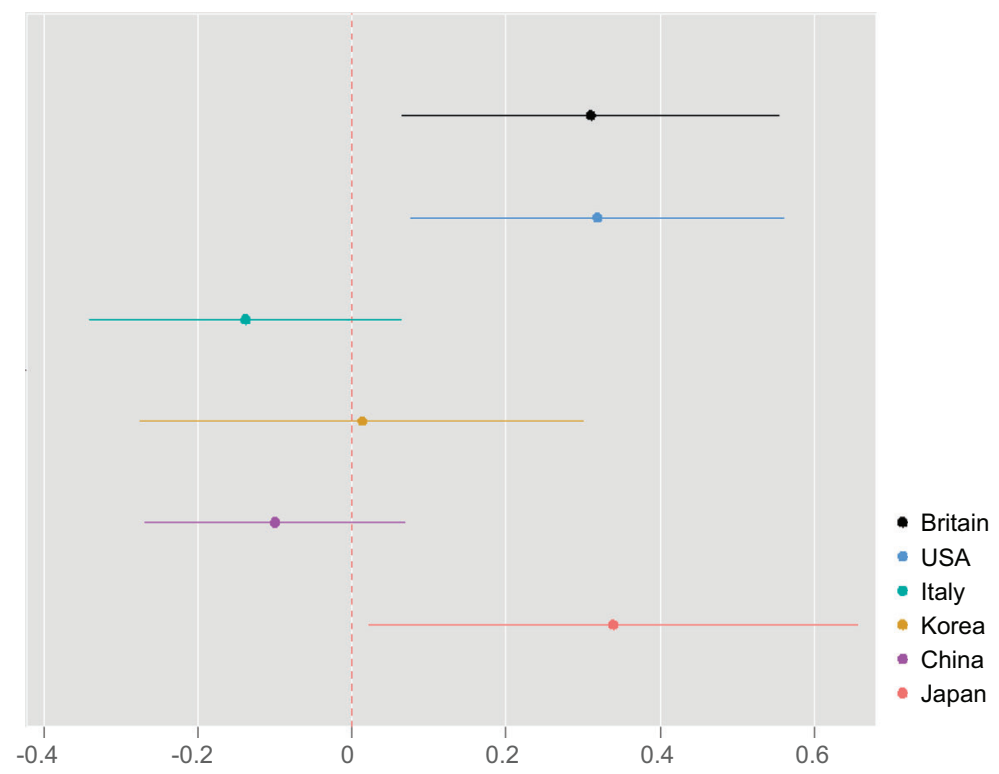

Corresponding author

Klarita Gërxhani can be contacted at: klarita.gerxhani@eui.eu

For instructions on how to order reprints of this article, please visit our website: www.emeraldgrouppublishing.com/licensing/reprints.htm Or contact us for further details: permissions@emeraldinsight.com 